University of Nebraska - Lincoln

DigitalCommons@University of Nebraska - Lincoln

Faculty Publications: Department of Entomology

September 1988

\title{
Use of Radiography in Behavioral Studies of Turfgrass-Infesting Scarab Grub Species (Coleoptera: Scarabaeidae)
}

M. G. Villani

New York State Agricultural Experiment Station, Geneva, NY

Robert J. Wright

University of Nebraska-Lincoln, rwright2@unl.edu

Follow this and additional works at: https://digitalcommons.unl.edu/entomologyfacpub

Part of the Entomology Commons

Villani, M. G. and Wright, Robert J., "Use of Radiography in Behavioral Studies of Turfgrass-Infesting Scarab Grub Species (Coleoptera: Scarabaeidae)" (1988). Faculty Publications: Department of Entomology. 110.

https://digitalcommons.unl.edu/entomologyfacpub/110

This Article is brought to you for free and open access by the Entomology, Department of at DigitalCommons@University of Nebraska - Lincoln. It has been accepted for inclusion in Faculty Publications: Department of Entomology by an authorized administrator of DigitalCommons@University of Nebraska - Lincoln. 


\title{
Use of Radiography in Behavioral Studies of Turfgrass-Infesting Scarab Grub Species (Coleoptera: Scarabaeidae)
}

\author{
M. G. VILLANI AND R. J. WRight
}

\begin{abstract}
The behavior of turfgrass-infesting scarab grubs in response to soil physical properties may affect the stress that each species exerts on turfgrass and the efficacy of control tactics. To gain a more realistic picture of the events that occur within the soil matrix, we have developed a nondestructive X-ray technique to study soil insect movement and behavior in simulated and natural soil blocks in the laboratory. Laboratory studies using this technique were done to determine the effect of some soil physical factors on scarab grub movement patterns. Species-specific differences were demonstrated in the responses of four scarab grub species (Japanese beetle, $P O$ pillia japonica Newman; European chafer, Rbizotrogus majalis (Razoumowsky); oriental beetle, Anomala orientalis Waterhouse; and northern masked chafer Cyclocepbala borealis (Arrow) ) to changing temperature and moisture conditions. Studies also were done to determine the effect of soil moisture on the movement and persistence of an insecticide (isofenphos) applied to turfgrass and its effect on European chafer grub movement and mortality. This study showed that isofenphos was relatively nonmobile under our experimental conditions, and that insecticide efficacy depended on factors, such as soil moisture, that influence the position of grubs in the soil profile. We believe that a better understanding of the interactions among grub behavior, insecticide persistence, and movement, as illustrated by this research, will improve our ability to manage scarab grubs in turfgrass and will be applicable to additional soil systems.
\end{abstract}

I N THE NORTHEASTERN United States, turfgrass is subject to intense feeding Lpressure from a complex of scarab beethes that cause extensive damage as immatures (Tashiro 1987). Although the adult behavior of many members is of the scarab pest complex and has been well studied, the species-specific behavior of the immature stages has been generally ignored. However, species-specific differences of scarab grubs in response to the physical properties of soil may affect the stress that each species exerts on turfgrass and the efficacy of control tactics.

Information about the behavior of scarab grubs is anecdotal in most instances because of the difficulty in studying the behavior of soil insects under natural conditions. There is a general perception that such research, if not impossible, is difficult, tedious, and not cost-effective when compared with similar studies of aboveground insects. This attitude has resulted in the soil ecosystem being treated as a black box in which the consequences rather than the processes of insect behavior are measured.

The control of soil insects that damage turfgrass and horticultural commodities has been inconsistent since the loss of the cyclodiene insecticides (Harris 1972, 1982; Baker 1986). One reason for this inconsistency is the lack of understanding of the interaction of the control tactic (chemical, biological, or genetic), the cropping system, the target insect, and physical (soil moisture, temperature, texture, and compaction) and biotic (presence of microbial flora and other organisms) environment of the soil. Although each of these factors has been independently studied by basic and applied researchers, their interdependence has been ignored in most studies.

Understanding the behavior of soil insects found in turfgrass is important to pest management because of the difficulty in moving soil insecticides down into the soil of established turfgrass. If thatch is in the upper soil profile, binding and degradation may increase with several soil insecticides (Niemczyk \& Krueger 1982, Niemczyk \& Chapman 1987). Physical factors that make target insects move as little as $1 \mathrm{~cm}$ into the soil profile may put these insects out of the effective active zone of chemical and biological control agents.

The failure in predicting soil insect damage and the costs of satisfactory control dictate a more systematic and comprehensive approach to soil insect research. Paramount to such an approach is the ability to monitor the response of soil insects to static and dynamic environmental factors in the soil and to manipulate these factors to determine changes in insect response. Understanding the fundamental differences in behavioral response among species of soil insects to a variety of typical soil factors will enhance our ability to predict the stress each species will inflict on a particular crop. An improved understanding of the interaction of the control agent and the target species with the soil environment should lead to changes in management practices that in crease the level of overlap between control agent and target pest.

In this paper, we describe a technique that uses radiography, which permits us to study soil insect behavior using nondestructive sampling and to make repeated observations over short intervals. We used this technique to study the movement behavior of several scarab grub species, and we present data that demonstrate the influence of soil moisture and soil temperature on vertical grub movement. We also used radiography and analytical chemical analysis to study the interaction of a turf insecticide, a grub species, and the simulated turf environment. Our aim was to illustrate how a combination of laboratory research techniques in model systems can be useful in improving our understanding of field phenomena.

\section{Radiography in Soil Insect Research}

Although there have been field studies that look at the movement of soil insects over long periods (Forbes 1907, Criddle 1918, McCollock \& Hayes 1923, Mail 1930, Dowdy 1944, Hawley 1949, LaFrance 1968 , Fisher et al. 1975), these studies considered the soil insects found in the top $5 \mathrm{~cm}$ as being at the surface layer. Detailed knowledge of the movement of grubs within the top $5 \mathrm{~cm}$ over short periods can have a profound effect on pest management.

Laboratory studies of the movement and feeding behavior of soil insects often were done outside the soil (Fulton 1928) or between thin sandwiches of glass plates and sterile, homogeneous sand (Doane et al.

MiCHAEL G. VILLANI is an assistant professor of soil insect ecology in the Department of Entomology, New York State Agricultural Experiment Station, Geneva N.Y. 14456. ROBERT J. WRJGHT is an entomologist formerly with Cornell University at the Long Island Horticultural Research Lab, Riverbead N.Y. He is currently an assistant professor with Department of Entomology, University of Nebraska, Lincoln, Nebr. 68583, serving as extension IPM specialist. 
1975), which strongly modified insect movement patterns. Villani \& Gould (1986) developed an X-ray technique that makes it possible to study soil insect movement and behavior within heterogeneous soil blocks. Prior use of this technique to monitor soil insect behavior has been limited to small arenas ( 30 by 4 by $15 \mathrm{~cm}$ ) in simulated soils. It also required the use of expensive $\mathrm{X}$-ray film and substantial darkroom time. We expanded this technique to study several species of scarab grubs in larger arenas (up to 35 by 12 by $43 \mathrm{~cm}$ with large grubs as subjects; smaller grubs require proportionally thinner arenas) and with field-collected soil blocks, and we used a paper rather than film base (this is approximately $90 \%$ cheaper, requires only $5 \mathrm{~s}$ to develop, and does not require a wet darkroom for processing). Radiographs of soil blocks are of sufficient quality for us to identify the location of grubs within the soil profile. Soil blocks retain their field characteristics (compaction, heterogeneity, and endemic floral and faunal communities) and therefore allow careful monitoring and manipulation of the system 'or long periods.

The radiographs were taken with the Hewlett-Packard Faxitron (model 43855B, Hewlett-Packard Company, Palo Alto, Calif.). This unit is a self-contained, radiationshielded cabinet X-ray system designed to give high-resolution radiographs of small to medium-sized objects. Millamperage is rated 3.00 and voltage is continuously variable with a range from 10 through $130 \mathrm{kV}$ (kilovoltage); this output allows for visualization of $2.5-\mathrm{cm}$ steel plate, $15-\mathrm{cm}$ aluminum plate, or their equivalent. Exposures for these studies were at $70 \mathrm{kV}$ for $20 \mathrm{~s}$ per exposure. An Industrex Instant Processor (model P-1, Kodak, Rochester, N.Y.) was used to produce fully processed radiographs on sheets of Kodak Industrex Instant 600 paper in $10 \mathrm{~s}$. The radiographs can be viewed in direct light. Fig. $1-5$ are examples of laboratory radiographs of scarab grubs. Fig. 1 shows a simulated soil block, and Fig. 2-5 are field-collected soil blocks ( 35 by 8 by $43 \mathrm{~cm}$ ).

\section{Scrab Grub Movement Monitored by Radiography}

All studies were conducted in Plexiglas arenas ( 35 by 5 by $43 \mathrm{~cm}$ ) filled with sieved loamy sand soil (organic matter content, 2.4\%; soil pH 6.9). These dimensions allowed the scarab grubs to move in all directions until the constraints of the walls were met. We needed a method for presenting data gathered through our radiography studies that provided a direct view of the location of the grub population in the soil profile. The use of boxplots (McGill et al.
1978) provided us with such a tool. These boxplots provide more useful information than does the use of means and variances (they allow identification of outliers, which may be important in studies of insect behavior), and they are more amenable to interpretation than is simple plotting of frequency distribution data.

Effects of Moisture Fluctuation. Many earlier reports (reviewed by Tashiro [1987]) indicate that grub species respond to soil moisture gradients differently. Our study examined the species-specific responses of four scarab grub species to conditions that simulate irrigation (or rainfall) and drought. We seeded each arena with about $3 \mathrm{~g}$ of a mixture (of $49 \%$ red fescue, Festuca rubra L.; 19\% Kentucky bluegrass, Poa pratensis L.; $15 \%$ perennial ryegrass, Lolium perenne L.; 14\% Chewings fescue, $F$ rubra commutata Gaud; and 3\% other) and then held at $20^{\circ} \mathrm{C}$ with a $12: 12$ (L:D) photoperiod for 7-10 wk. Each arena was then infested with 10 third-instar grubs of one of four species (European chafer [EC], Rbizotrogus majalis (Razoumowsky); Japanese beetle UB], Popillia japonica Newman; oriental beetle [OB], Anomala orientalis Waterhouse; and northern masked chafer [MC], or Cyclocepbala borealis (Arrow)), with a total of 30 grubs of each species ( 3 arenas for each scarab grub species). Grubs were placed on the turfgrass and allowed to dig down. Grubs that did not dig into the soil within $1 \mathrm{~h}$ were replaced. Within $48 \mathrm{~h}$ after infestation, the arenas were placed in continuous darkness at $20^{\circ} \mathrm{C}$ for the duration of the experiments.

The scarab grubs were collected in the fall or spring from turfgrass at different sites (one site per species in each study) in New York from areas that had not been treated with insecticides that year. Grubs collected in the fall were stored at $10^{\circ} \mathrm{C}$ in soil covered with sod for up to 4 mo until they were used in these studies. Grubs collected in the spring were used within $2 \mathrm{wk}$ of their collection.

Test 1. Response to Irrigation. Soil moisture was measured gravimetrically at intervals throughout the soil profile at the beginning and end of the study ( 0 and $315 \mathrm{~h}$ after infestation [HAI]). Infested arenas were Xrayed at $4,8,12,24,32,48,56,72,80,104$, $128,152,176,200$, and 224 HAI. Water ( 100 $\mathrm{ml} /$ arena) was added at 32 and $200 \mathrm{HAI}$ to simulate irrigation of a soil with $1.0 \mathrm{~cm}$ of water. This is the amount recommended in New York after application of soil insecticides for control of scarab grubs in turfgrass (Smith \& Wilson 1987). At the end of the study, each box was X-rayed and then taken apart, and the position of each grub was recorded. Any dead grubs identified at this time were traced back in time by ex- amining X-rays that had been made up to the point when the grub stopped changing positions. All data following the last change in position were removed from the analysis.

Fig. 6a shows the changes in moisture throughout the soil profile from the start of the experiment to the final sampling. Water was added to the arenas at $32 \mathrm{~h}$, and it moved slowly through the soil profile. Parallel studies that used probes to measure soil moisture tension at $2.5,5,10$, and $20 \mathrm{~cm}$ indicated that the moisture front reached the $10-\mathrm{cm}$ point in approximately $48 \mathrm{~h}$ and did not move beyond that point for the duration of the study. Soil moisture remained fairly constant in the upper profiles of the arenas until approximately hour 200, when additional water was added.

The rate of movement of each species and the changes in population distribution can be displayed easily with boxplots. Fig. 7 illustrates the information provided by the boxplot display of the grub position data. Although not shown, boxplots can be used to determine statistical differences within species over time and among species for a single period of observation (McGill et al. 1978). The $\mathrm{X}$-ray procedure allowed us to monitor the response of the same population to changing moisture conditions over time (Fig. 8). In terms of the responses of the medians over time, all species moved upward after water was added. However, wide differences in response can be seen in the four grub species in terms of the response of population medians and in the degree of variation around the median. Of particular note in these boxplots is the initial movement of all grub species downward from regions of low soil moisture to regions of higher soil moisture.

In all cases, the shapes of the curves are similar, but the magnitude of the movement and the rate of population response are species specific. The most dramatic movement patterns are in the response of EC to dry soil conditions and the protracted movement of the population back toward the soil surface. We believe that EC grubs that contact the moisture front move rapidly to the surface. Relatively slow population response (as indicated by the extended lower tail of the boxplots) can be attributed to lack of contact between grubs and moisture in the lower soil profile. The movement of all species downward in the profile toward the end of the study may be a response to slightly lower soil moisture in the upper 2.5 $\mathrm{cm}$ of soil (Fig. 8) and also may involve a behavioral response to the prepupal state.

Test 2. Response to Drought Simulation. Procedures for the second test were similar to those in Test 1, except that the soil was allowed to dry during the study period. This study was conducted to determine whether 


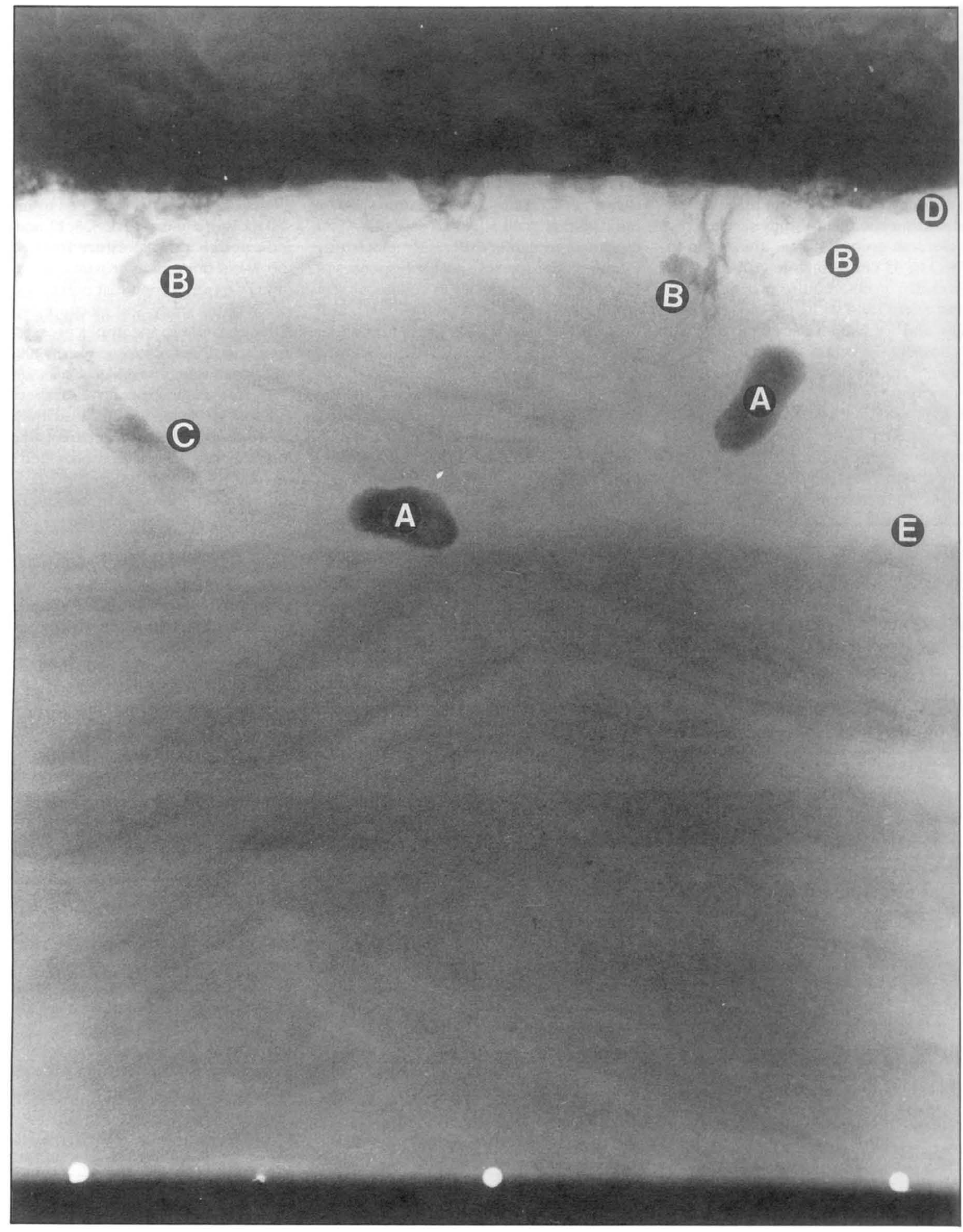

Fig. 1. Radiograph of simulated uniform-texture soil (loamy sand) containing two species of scarab grub. Two moisture levels can be seen (E); differences in radiograph tone density are attributable to differences in soil matrix density. The lighter upper surface indicates greater levels of soil moisture. The moisture fills most micro- and macro pores. The lower stratum contains less moisture and more air in the soil pores, which increases the penetration of X-rays to the film. Two large Phyllophaga sp. grubs (A) are seen in their arenas; three smaller JB grubs (B) are closer to the surface of the soil (D). Although the soil conditions are not ideal to show tunneling, one Phyllophaga $s p$. burrow $(C)$ can be seen. Note the apparent stratification by species and the location of the Phyllophaga sp. at the soil moisture interface. 


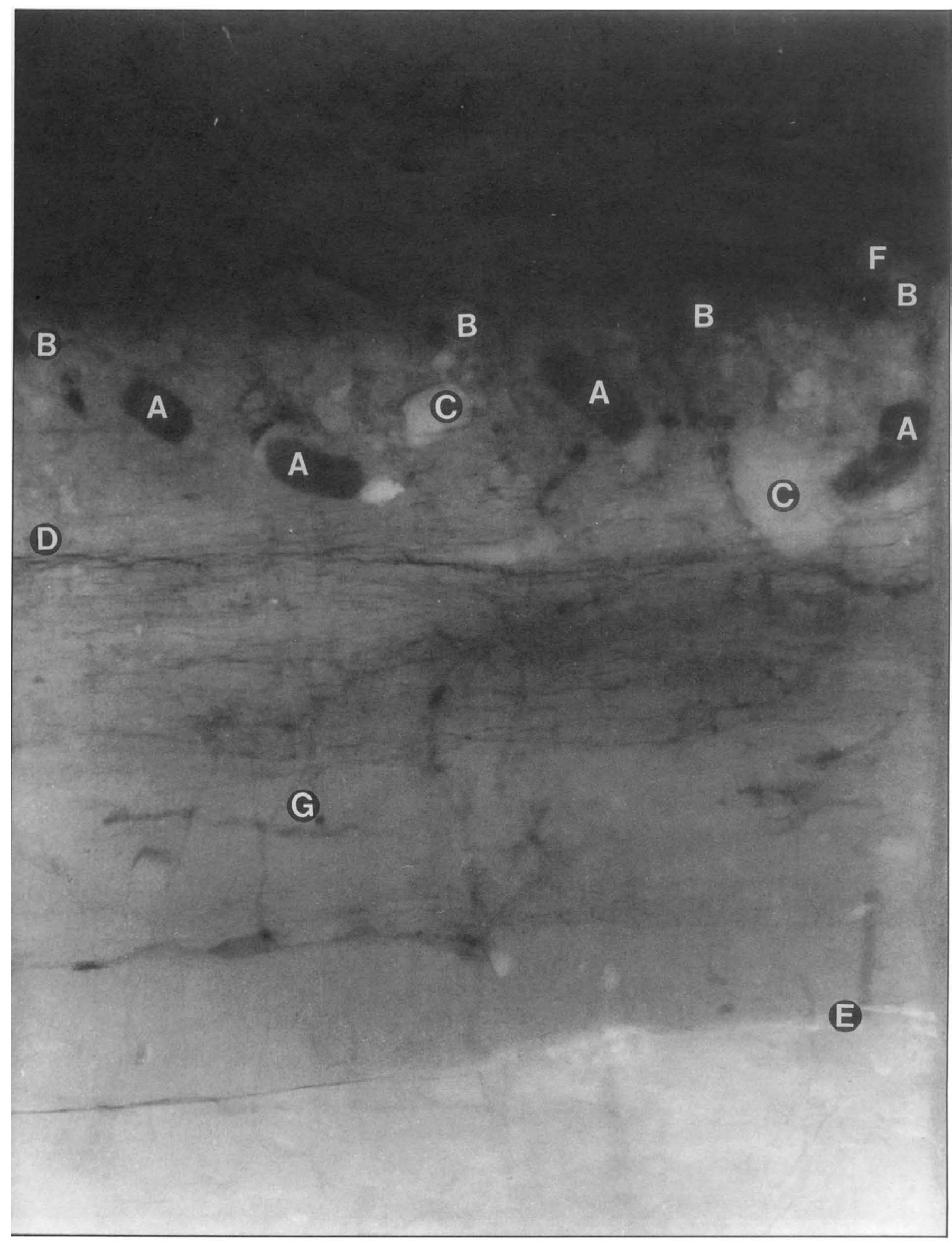

Fig. 2. Radiograph of a soil block taken from moist, stratified soil of a weedy orchard. Two grub species (A, Phyllophaga sp.; B, EC) were introduced to the top of the soil (F) 3 d before the radiograph was made. A, third-instar Phyllophaga sp.; $B$, third-instar EC; $C$, rock; $D$, interface of topsoil and sandy borizon (cracking is due to collection); F, soil surface; G, burrows of soil organisms captured in soil block, most likely small earthworms. 
B

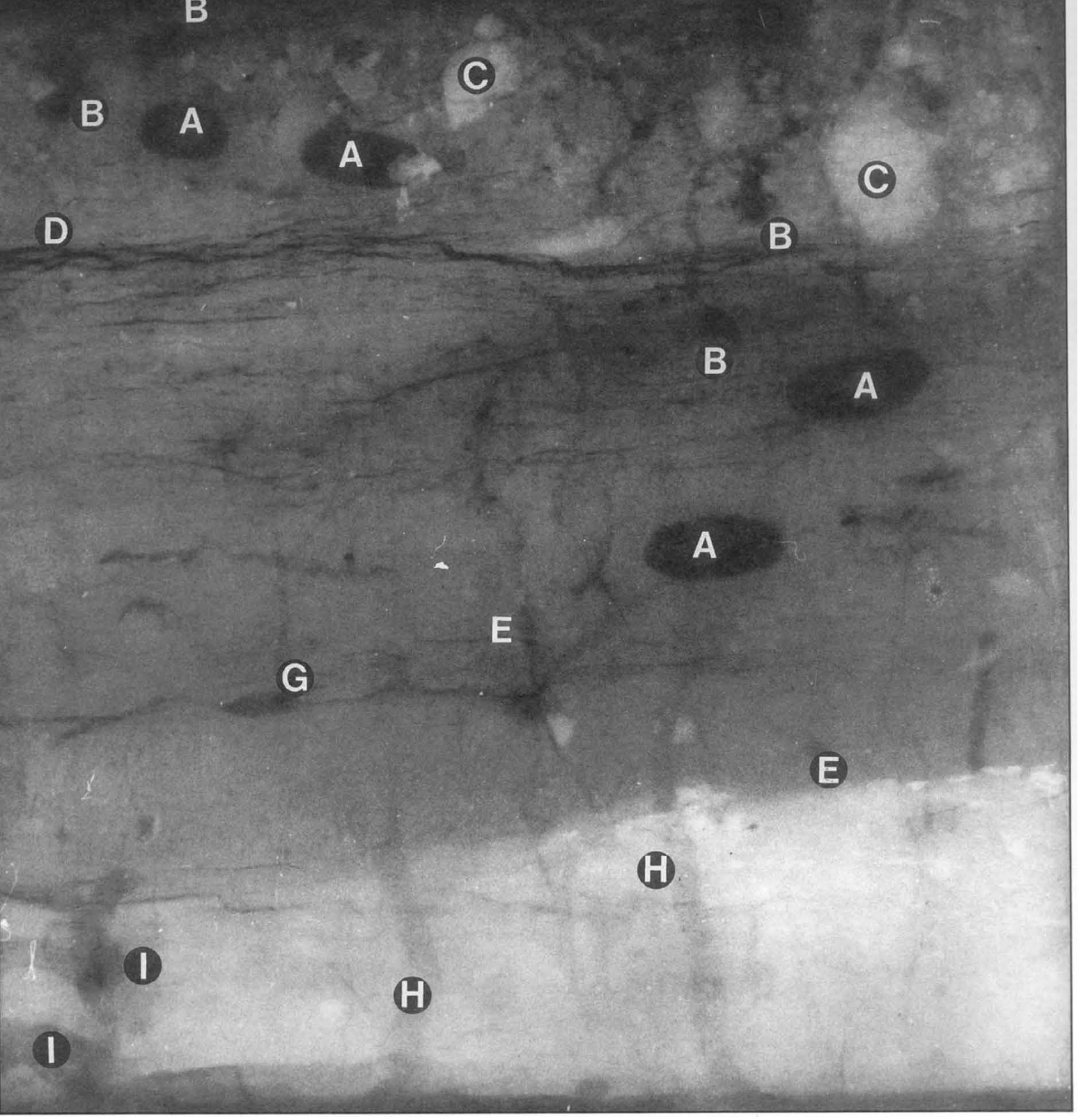

Fig. 3. Radiograph of a soil block taken from moist, stratified soil of a weedy orchard (see Fig. 2). Soil was allowed to dry for 2 wk before this radiograph was made. Grubs of Phyllophaga sp. and EC have moved down in response to drying conditions. A, third-instar Phyllophaga sp.; B, third-instar EC; $C$, rock; $D$, interface of topsoil and sandy borizon; $E$, interface of sandy borizon and clay borizon; $F$, soil surface; $G$, burrows of soil organisms; $H$, burrows of tunneling Phyllophaga sp. grub before reaching final position; I, prior location of Phyllophaga sp. grubs. 


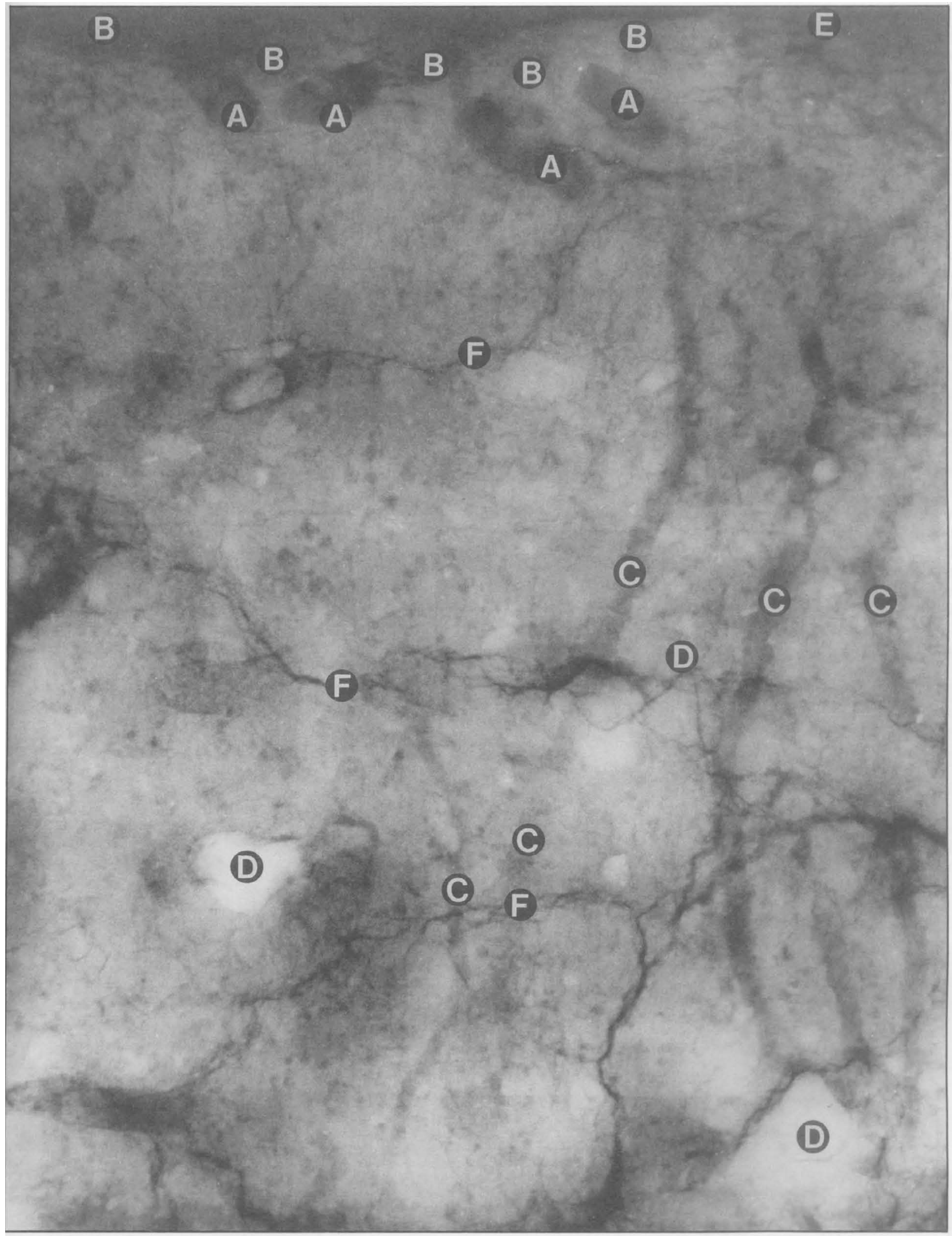

Fig. 4. Radiograph of a uniformly wet soil block taken from below turf grass with deep topsoil (no stratification). Two grub species (A, Phyllophaga sp.; B, EC) were introduced to the top of the soil (E) 3 d before this radiograph was made. A, third-instar Phyllophaga sp.; $B$, third-instar EC; $C$, earthworm burrows; D, rock; E, soil surface; F, artifact (soil cracks most likely result of collection process). 


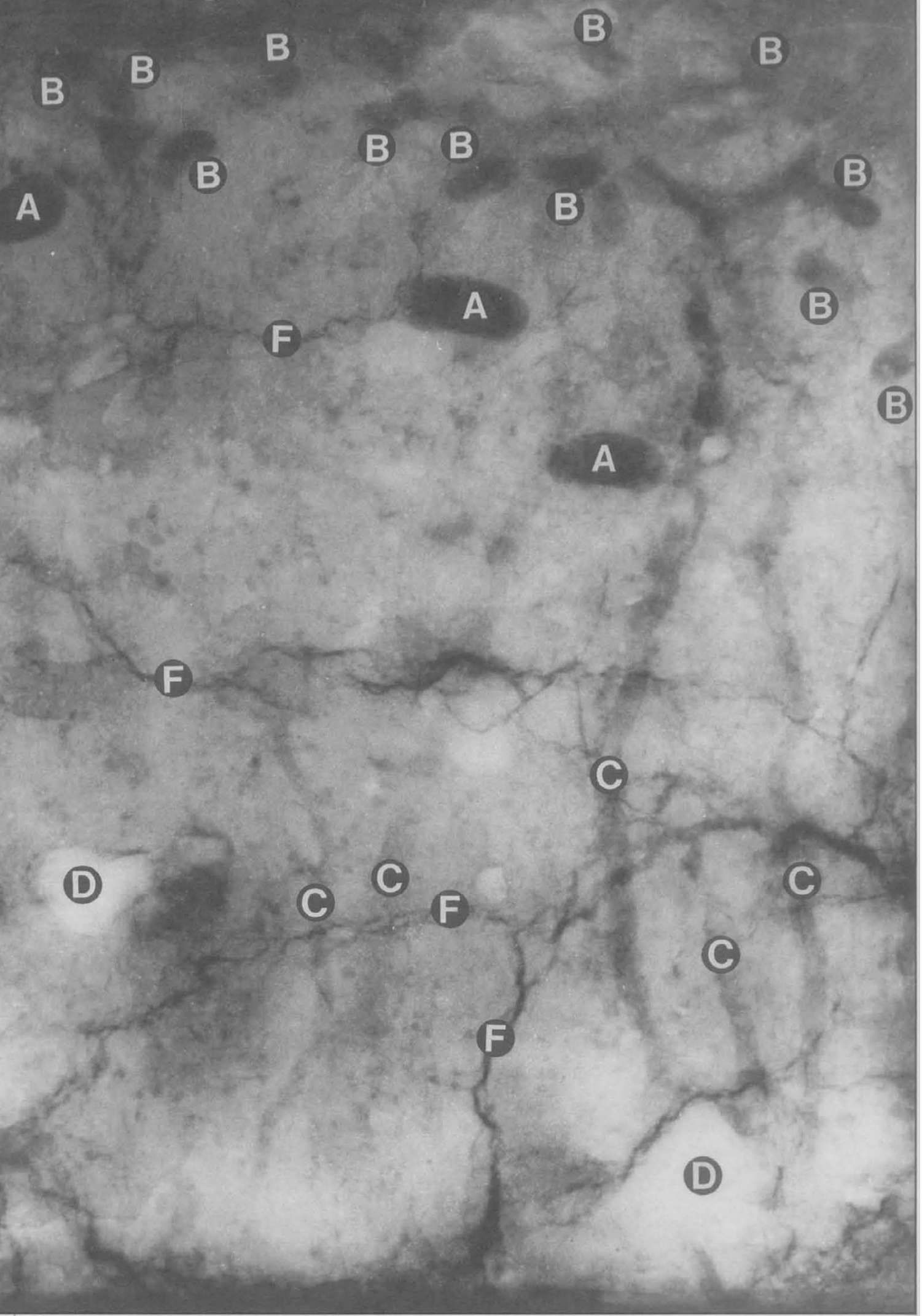

Fig. 5. Radiograph of a uniformly wet soil block taken from below turf grass with deep topsoil (no stratification). At the end of 1 wk, both species have moved down from positions shown in Fig. 4. A, third-instar Phyllophaga sp.; B, third-instar EC; $C$, earthworm burrows; $D$, rock; $E$, soil surface; $F$, artifact (soil cracks most likely result of collection process). 


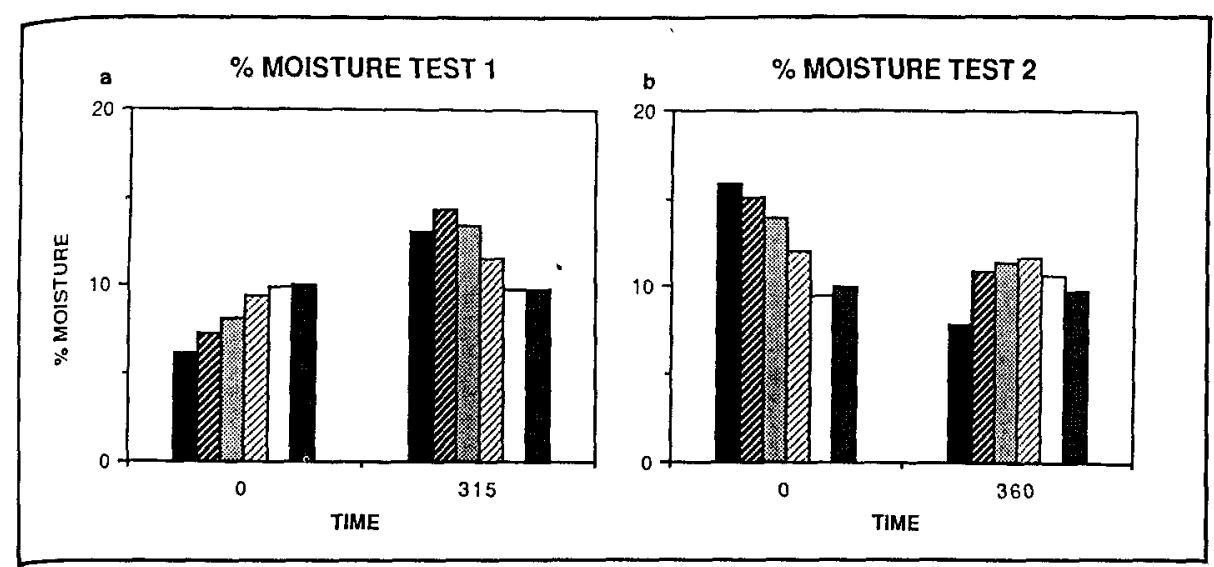

Fig. 6. Changes in soil moisture throughout the profile from (a) the start of Test 1 to (b) Test 2 to the period of final sampling. Histogram bars (left to right) show percentage moisture at soil depth of $0-2.5,2.5-5.0,5.0-7.5,7.5-15.0,15.0-22.5$, and $22.5-30.0 \mathrm{~cm}$.

there is a species-specific response by scarab grubs to simulated drought (gradual moisture loss beginning at soil surface and extending down into the profile over time). This phenomenon is common during late summer in nonirrigated turfgrass. X-rays were made at $6,30,54,78,102,126,150,174$, $198,222,246,318$, and $360 \mathrm{HAI}$.

The moisture profile indicates a gradual switch in the direction of the soil moisture profile (Fig. 6b). The soil moisture at the 0 $2.5-\mathrm{cm}$ level at $360 \mathrm{~h}$ is $7.9 \%$, which is not extremely dry. Despite this, $\mathrm{MC}, \mathrm{JB}$, and $\mathrm{OB}$ all showed a strong trend toward moving downward into the soil as moisture decreased from the surface (Fig. 9). EC grubs showed the least sensitivity to decreased soil moisture, which may be related to their ability to escape rapidly from extreme conditions (Fig. 8). Although a majority of the $\mathrm{EC}$ and $\mathrm{OB}$ populations remained in the upper soil levels when soil moisture was high, a number of the grubs moved downward into the profile. Reasons for this variation must be explored in future studies.

Effects of Temperature Fluctuation. Plexiglas arenas as described above were seeded with grass seed (mixture identical to that used in the moisture study). Then, field-collected turfgrass sod (predominantly Poa annua L.), which had been washed to remove most of the soil, was placed on top of the seeded soil in each arena. Each arena was infested with 10 third-instar grubs of one of the three species $(\mathrm{EC}, \mathrm{JB}, \mathrm{OB}$ ). Thirty grubs per species ( 3 arenas/species) were exposed to fluctuating temperatures; an additional 30 grubs per species ( 3 arenas $/$ species) were held at $20^{\circ} \mathrm{C}$ for the duration of the experiment.

Following infestation, all arenas were covered with plastic to minimize fluctuations of soil moisture, which averaged $14 \%$ during the study. All arenas were held in the dark during the experiment. In an attempt to simulate temperature change in the field, tions in the stable and shifting treatments with this species were indistinguishable (boxplot comparisons). This lack of response to temperature in the model turf system conforms to field observations (Tashiro 1987; M. G. V., unpublished data), which indicate that EC grubs are often found in the upper soil profile well into early winter and early spring, and that at times, they feed in the upper root zone (roots of Kentucky bluegrass may extend down into the soil $1 \mathrm{~m}$ under favorable conditions) under snow if this zone is not frozen.

In contrast, the two other species showed a marked response to shifting temperatures. JB grubs fed in the upper soil profile in the stable-temperature regime, but in the shifting-temperature regime, grubs moved from the upper soil downward with the onset of soil cooling $\left(14^{\circ} \mathrm{C}\right)$ and returned to the surface as temperatures increased. The behavior of $\mathrm{OB}$ grubs appeared more variable in both treatments, as it had in the moisture studies, but there was a clear trend for grubs to remain in the upper soil in the stable treatment and to respond to lower soil temperatures $\left(8^{\circ} \mathrm{C}\right)$ by moving down into the soil profile. With an increase in soil temperature, a portion of the $\mathrm{OB}$ population appeared to move back toward the soil surface, but this did not affect the median population value. This movement phenomenon with $O B$ populations in response to warming has been observed in the field (R. J. W., unpublished data).

These studies, which used a nondestructive radiographic technique, have demonstrated species-specific differences in scarab grub response to changing temperature and moisture conditions. The differences involved changes in the population median and in overall population distribution. Boxplots are particularly useful in summarizing this kind of data. Increased knowledge of species-specific movement patterns of scarab grubs in turfgrass in re-

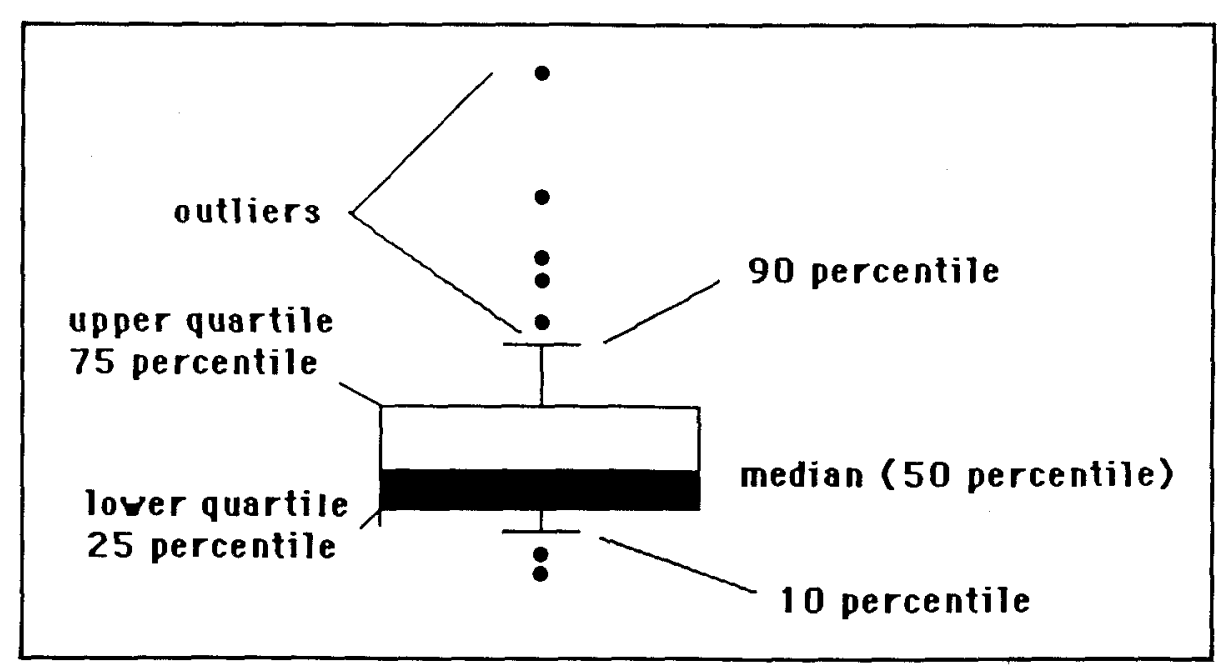

Fig. 7. Information provided by boxplots used to display grub position data. 

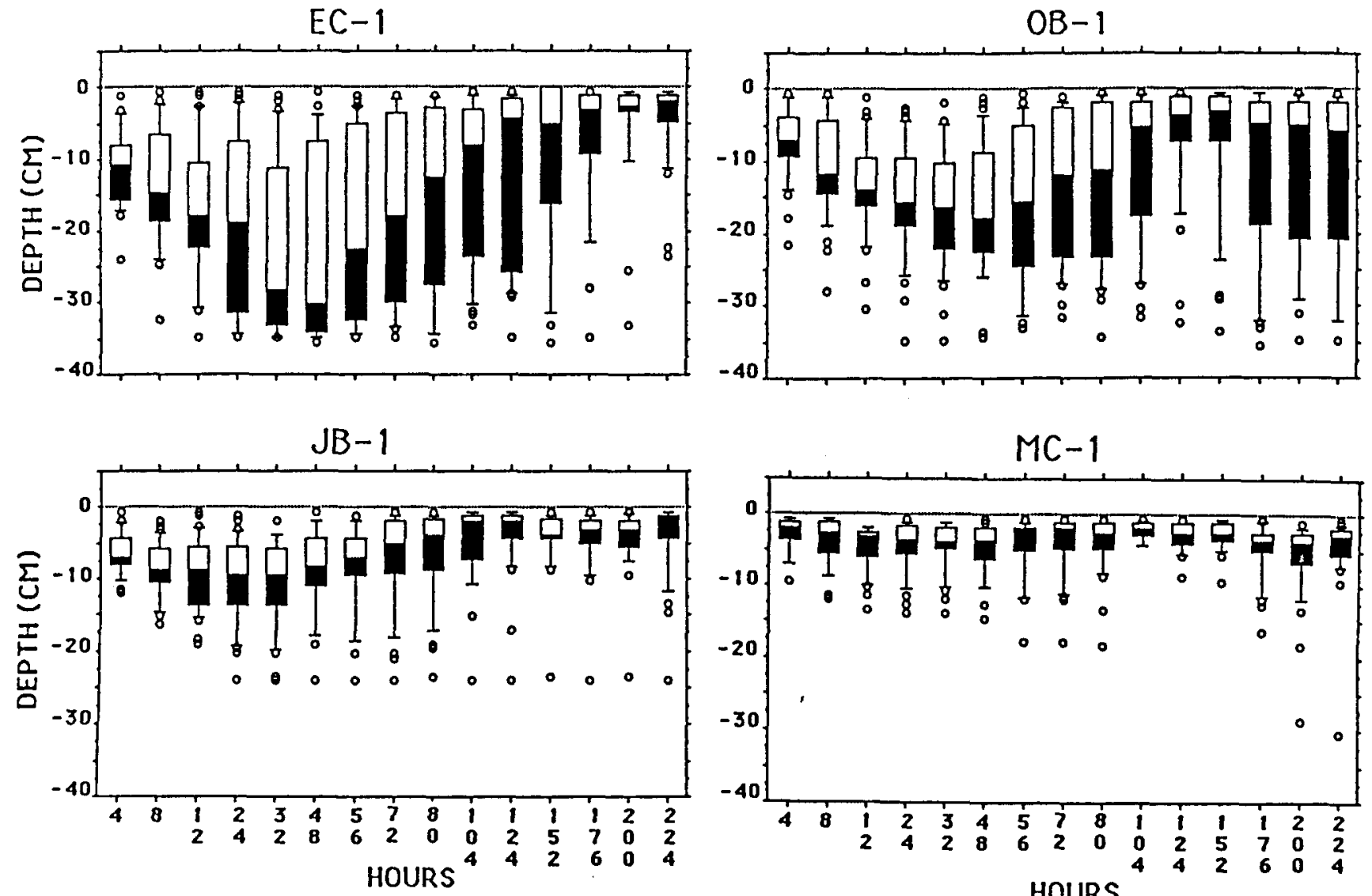

HOURS

Fig. 8. Boxplots of grub position data taken from radiographs for Test 1. EC-1, European chafer; OB-1, oriental beetle; JB-1, Japanese beetle; $M C-1$, northern masked chafer.

sponse to these and other soil environmental factors, if substantiated in field studies, will have practical applications in developing more effective management systems for these soil insects. Such information will help determine the probability of overlap of a specific grub species with a specific control agent in space and time, suggest a depth to which sampling for grubs must occur in sampling and monitoring programs, and indicate the hidden population of grubs when sampling within the turfgrass soil profile.

\section{Interaction of Insecticides and Grub Movement}

Historically, effective long-term control of the scarab grub complex was achieved with the cyclodiene insecticides. Less consistent control has been achieved with the many organophosphate and carbamate insecticides that replaced them (Baker 1986). Several factors, including soil $\mathrm{pH}$, organic matter content, moisture, timing of application, thatch, and microbial degradation of insecticides, influence the efficacy of currently registered insecticides (Harris 1972, Tashiro \& Kuhr 1978, Kuhr \& Tashiro 1978, Tashiro 1982, Harris 1982, Niemczyk \& Krueger
1982, Chapman 1982, Vittum 1985, Niemczyk \& Chapman 1987, Racke \& Coats 1987). JB resistance to organophosphate insecticides also has been documented ( $\mathrm{Ng} \& \mathrm{Ah}$ mad 1979, Ahmad \& Ng 1981). An additional factor that current research points to as being critically important is the ability of the soil insecticide to reach the target insect species (Niemczyk 1987). The generally low persistence and solubility and the high organic-content-binding properties of soil insecticides labeled for turfgrass insect control have led to situations in which some soil insecticides may not reach the target population in the field

The loss of highly persistent soil insecticides through insecticide resistance and legislation has necessitated the use of less persistent compounds. Several studies (Niemczyk et al. 1977, Kuhr \& Tashiro 1978, Chapman 1982, Sears \& Chapman 1982, Tashiro 1982, Niemczyk 1987) have shown that the less-persistent organophosphate and carbamate insecticides degrade more rapidly than the cyclodiene soil insecticides do; therefore, there is less time for them to move into the soil. Diazinon applied to turfgrass degrades so rapidly that $<1 \%$ of the original concentration is present in the upper soil profile $14 \mathrm{~d}$ after treatment (Sears $\&$
Chapman 1982). Chlorpyrifos is considered one of the more persistent organophosphate insecticides, but Kuhr \& Tashiro (1978) found that $<1 \%$ of the original concentration of this pesticide could be recovered from the thatch-root zone $56 \mathrm{~d}$ after application. These results indicate that there is a relatively narrow window of time in which turfgrass insecticides can be applied to obtain consistent control. Niemczyk (1987) and Niemczyk \& Krueger (1982) report that if appreciable levels of thatch are present, only limited amounts of insecticides move through the thatch into the soil.

C. R. Harris reviews the problems of controlling soil insects with insecticides in general (Harris 1972) and soil insects in turfgrass and pastures in particular (Harris 1982). He puts forth the following argument:

During the past 20 years this problem [lack of effectiveness of short-residual soil insecticides in controlling soil insects] has received considerable attention and a number of factors have been shown to influence insecticide activity in the soil including: the physiochemical properties of the insecticide; soil and climactic factors; insect susceptibility to insecticides and insect 


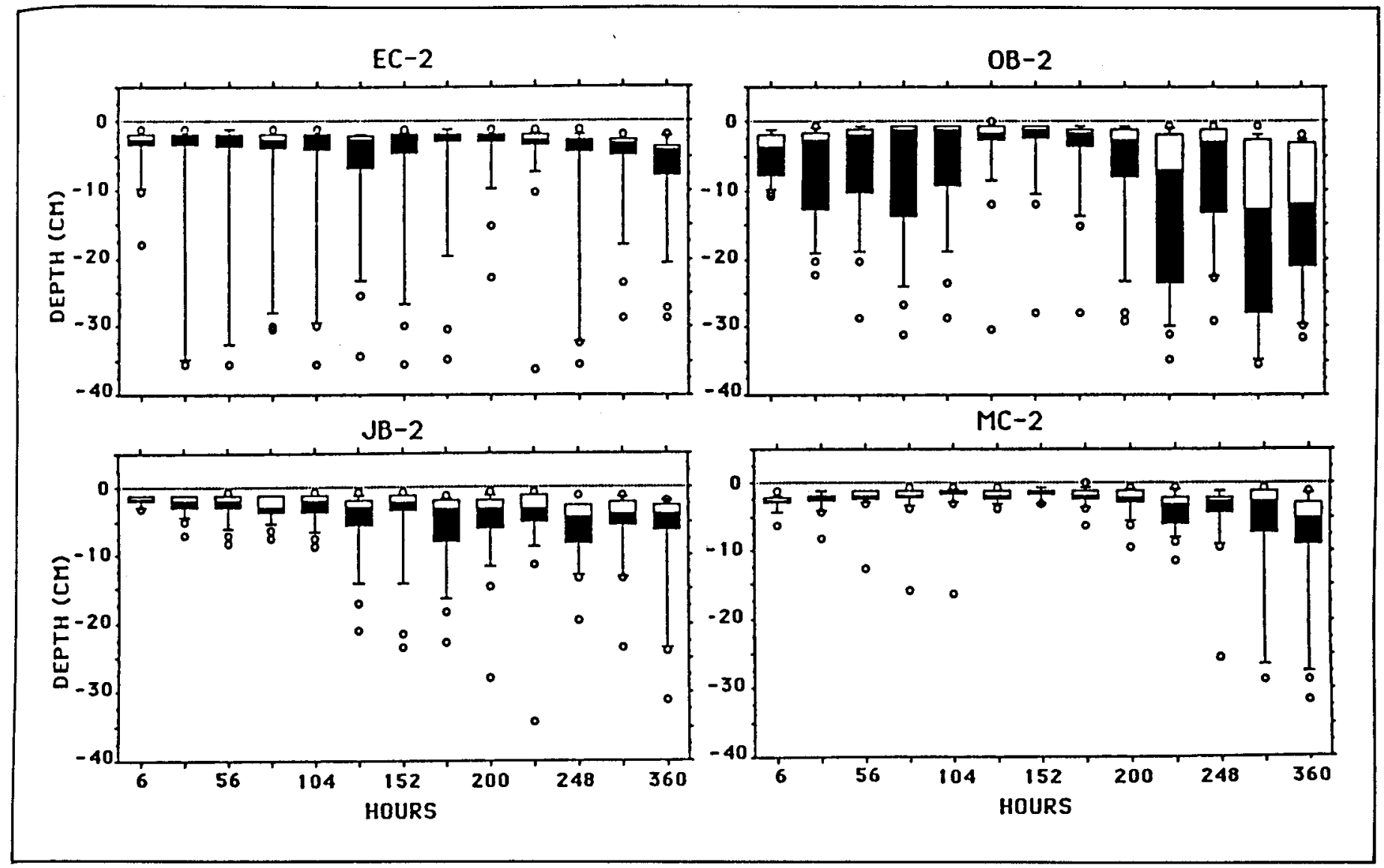

Fig. 9. Boxplots of grub position data taken from radiographs for Test 2. EC-2, European chafer; OB-2, oriental beetle; JB-2, Japanese beetle; $M C-2$, northern masked chafer.

behavior in the soil. ... A factor that has received little attention, other than in a very general sense, is the way insect behavior will influence the effectiveness of soil insecticides. For the immediate future, the most promising research possibilities are in the area of soil insect ecology. With greater comprehension of the factors influencing the behavior and development of soil insects, it would be possible to utilize insecticides far more effectively.

Effect of Irrigation on Scarab Grub and Insecticide Behavior

Soil insecticides are more effective in controlling scarab grubs in turfgrass when they are irrigated into the soil with at least 1 $\mathrm{cm}$ of water; it has been assumed that this irrigation helped the active compound move off the turfgrass through the thatch to the upper soil profile where scarab grubs feed (Vittum 1986). The following study suggests that irrigation may move the scarab grubs up in the soil profile rather than move the insecticide down to the grubs.

The study was conducted in soil arenas as described in studies of the effects of moisture fluctuation. Each arena was infested with 10 third-instar EC grubs, and there were eight replications of each of four treatments (Table 1).

Arenas were X-rayed at $0,24,96,166$, and $360 \mathrm{~h}$ after treatment. An additional $75 \mathrm{ml}$ water was added to Treatments 2 and 4 at $166 \mathrm{~h}$. Soil moisture tension was monitored continuously with soil probes at 2.5 and 10 $\mathrm{cm}$ depth in two additional infested arenas, one each from Treatments 3 and 4. Residue samples (200 $\mathrm{g}$ [wet weight] soil/sample) were taken $24 \mathrm{~h}$ after treatment from additional infested and treated arenas that had received Treatments 1 and 2 .

Grub condition (normal, moribund, or dead) and location (depth below soil surface) were recorded at the end of the study ( $360 \mathrm{~h}$ after treatment) by taking the arenas apart. Soil moisture was measured gravimetrically at this time by taking samples (50 $\mathrm{g}$ [wet weight] soil/sample) at intervals through the soil profile from all arenas. Residue samples were taken from the soil sur- face (the grass was clipped and the surface was scraped to $<1 \mathrm{~mm}$ ) and at intervals through the soil profile (soil depths of 0 $2.5,2.5-5.0,5.0-7.5,7.5-15.0,15.0-22.5$, and $22.5-30.0 \mathrm{~cm}$ ) of treated arenas. Additional untreated soil samples were collected and treated with $10 \mu \mathrm{g}$ of isofenphos as a control. All residue samples were stored at $-18^{\circ} \mathrm{C}$ until analyses were conducted.

Soil samples were thawed for 15-30 min and a 120-g subsample was weighed out and air dried for $4 \mathrm{~h}$ at $20^{\circ} \mathrm{C}$. Samples were extracted with $300 \mathrm{ml}$ redistilled acetone for $1 \mathrm{~h}$ and then filtered through a Buchner funnel using Whatman no. 1 filter paper and suction. The acetone filtrate was filtered again through a Buchner funnel after the addition of a clean piece of filter paper and $75 \mathrm{~g}$ granular anhydrous sodium sulfate $\left(\mathrm{Na}_{2} \mathrm{SO}_{4}\right)$, and rinsed again with $50 \mathrm{ml}$ acetone. The sample volume was adjusted to $500 \mathrm{ml}$ and then a $50-\mathrm{g}(250 \mathrm{ml})$ aliquot was removed and evaporated to dryness in a

\begin{tabular}{cll}
\hline \multicolumn{2}{l}{ Table 1. Irrigation and insecticide rates } & \multicolumn{1}{c}{ Water added } \\
\hline \hline Treatment & \multicolumn{1}{c}{ Isofenphos $^{a}$} & $50 \mathrm{ml}(0.33 \mathrm{~cm}$ irrigation $)$ \\
1 & $2.24 \mathrm{~kg}(\mathrm{AI}) / \mathrm{ha}$ & $150 \mathrm{ml}(1.0 \mathrm{~cm}$ irrigation $)$ \\
2 & $2.24 \mathrm{~kg}(\mathrm{AI}) / \mathrm{ha}$ & $50 \mathrm{ml}$ \\
3 & None & $150 \mathrm{ml}$ \\
\hline
\end{tabular}




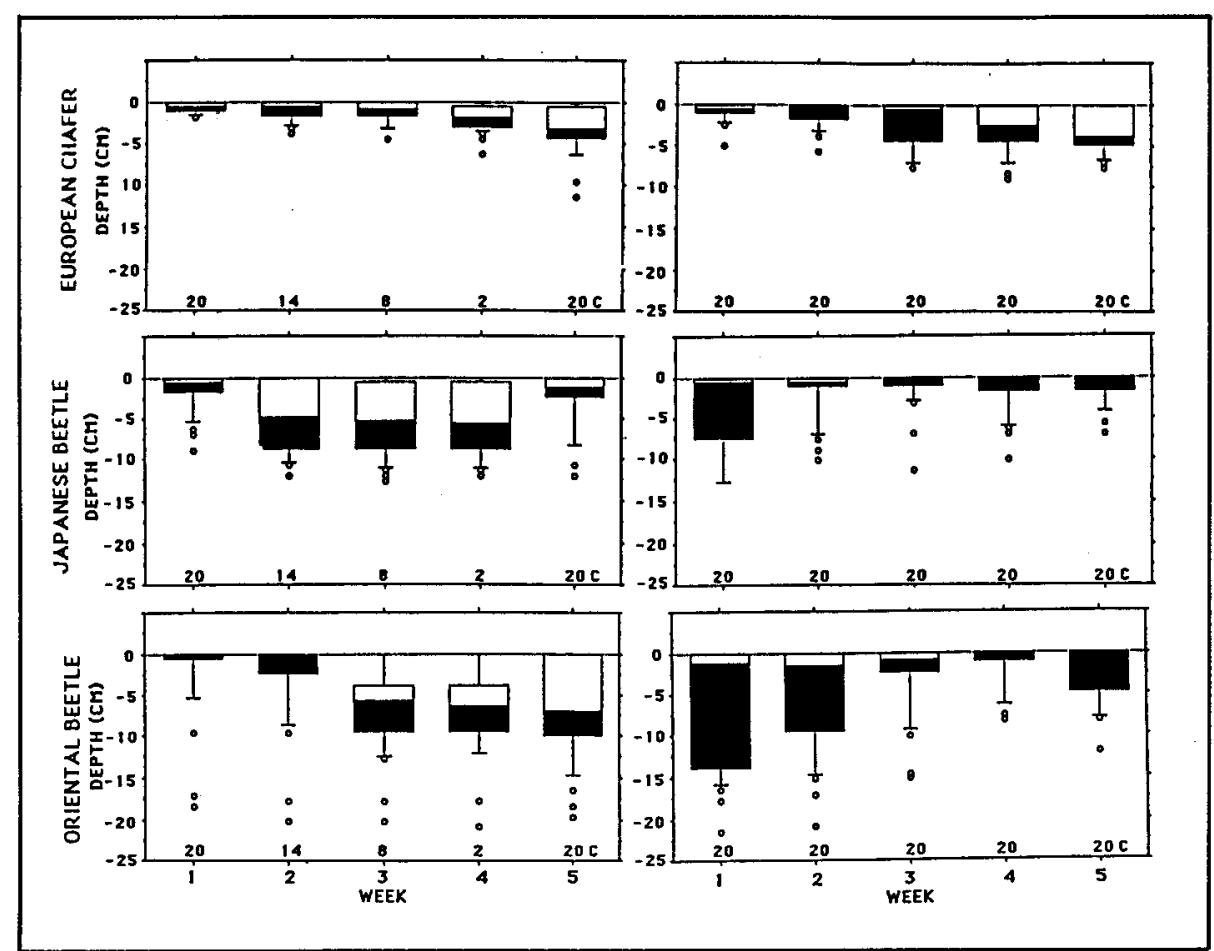

Fig. 10. Response of $E C, J B$, and $O B$ grub populations to fluctuations in soil temperature (a), Fluctuating treatment; (b), stable treatment.

water bath at $45^{\circ} \mathrm{C}$. Ethyl acetate (high-pressure liquid chromatography grade) was added to make a total volume of $10 \mathrm{ml}$ and then frozen. Isofenphos residues were analyzed by gas chromatography (Tracor 222, Tracor Instruments, Austin, Tex.) using a no. 12 column ( $183 \mathrm{~cm}$ tall) packed with $8 \%$ QFI and 3\% OV-17 on GasChrom Q (80-100 mesh) (Alltech Associates, Deerfield, Ill.). The injector was maintained at $220^{\circ} \mathrm{C}$ and the carrier gas was nitrogen. For each sample, the column temperature was programmed to increase from 175 to $250^{\circ} \mathrm{C}$ at a rate of $10^{\circ} \mathrm{C} / \mathrm{min}$. Detection was with a flame photometric detector (model FPD 100AT, Meloy Laboratories, Springfield, Va.) with a phosphorus filter and maintained at $195^{\circ} \mathrm{C}$. The limit of determination was 0.045 ppm.

The results indicate that there was little movement of insecticide past the $0-2.5-\mathrm{cm}$ level of soil regardless of the irrigation applied (Table 2). There was a significant loss of active material (percentage recovered) in the high-moisture treatment after $360 \mathrm{~h}$ when compared with the dry condition. A large proportion of the insecticide recovered remained on the soil surface $(<1$ $\mathrm{mm}$ ) in both treatments. The percentage of control was identical in both treatments after $15 \mathrm{~d}$. However, there was a higher proportion of morbid grubs in the higher moisture treatment; these grubs die within $14 \mathrm{~d}$ in most cases (M. G. V., unpublished data). These results indicate that insecticides do not move into the profile in response to simulated irrigation, and they suggest that
$2.5 \mathrm{~cm}$ deep (high insecticide concentration); $2.5-5 \mathrm{~cm}$ and $>5 \mathrm{~cm}$ (no insecticide detected, $\leq 0.045 \mathrm{ppm}$ ). Addition of water brought grubs to the surface in all treatments (data at $24 \mathrm{~h}$ ). The activity of the insecticide (as indicated by the general lack of grub movement in response to changing soil factors when compared with untreated arenas) becomes apparent in both moisture regimes between 96 and $166 \mathrm{~h}$. There is a slight difference in grub population distribution within moisture regimes between control and treated arenas. Differences in the distribution of the grub population between moisture levels in the control arenas began to occur at $96 \mathrm{~h}$; grubs in low-moisture control arenas began to move down in the profile, whereas those in high-moisture regime remained near the surface, potentially in contact with insecticide. Grubs in high-moisture control arenas began to respond to a slight decline in soil moisture at $166 \mathrm{~h}$. Note that moisture levels at $360 \mathrm{~h}$ in these arenas were greatest at the $>5 \mathrm{~cm}$ level. Clearly, fluctuation of soil moisture within the soil profile had an effect on insecticide persistence and on EC grub movement patterns, and these effects influenced the efficacy of isofenphos in the soil.

grub mortality will be higher in high-moisture arenas despite lower total insecticide recovery.

Fig. 11 shows the shift in the soil moisture profile for the high- and low-moisture treatments over the duration of the experiment. Twenty-four $h$ after water was added to the low-moisture arenas, the percentage of moisture in the soil profile remained fairly uniform with a slight (but important) rise in the first $2.5 \mathrm{~cm}$; the soil continued to dry until $360 \mathrm{~h}$, when a strong moisture gradient was observed. Twenty-four $h$ after moisture was added to the high-moisture arenas, there was a strong trend for moisture to decrease with increased soil depth. Soil moisture remained uniformly high but there was a slight (but important) drop in the top $2.5 \mathrm{~cm}$ of soil.

Data on grub position in each treatment (Fig. 12) were grouped at levels that are important with regard to the observed pesticide movement in the arenas (Table 2): $0-$

\begin{tabular}{|c|c|c|c|c|c|c|c|}
\hline \multirow[b]{2}{*}{ Treatment } & \multicolumn{5}{|c|}{ Isofenphos residues } & \multicolumn{2}{|c|}{ EC grubs } \\
\hline & $\begin{array}{l}\text { Time } \\
\text { (h) }\end{array}$ & $\begin{array}{l}\text { Depth } \\
\text { (cm) }\end{array}$ & $\mathrm{ppm}$ & \% recovered & $\%$ on surface & $\%$ control & $\%$ normal \\
\hline Dry & 24 & $\begin{array}{l}0-2.5 \\
>2.5\end{array}$ & $\begin{array}{l}2.78 \\
\mathrm{ND}^{b}\end{array}$ & 62.5 & & & \\
\hline Moist & 24 & $\begin{array}{l}0-2.5 \\
>2.5\end{array}$ & $\begin{array}{l}1.92 \\
\text { ND }\end{array}$ & 74.0 & & & \\
\hline Dry & 360 & $\begin{array}{l}0-2.5 \\
>2.5\end{array}$ & $\begin{array}{l}2.67 \\
\text { ND }\end{array}$ & 65.25 & 47.38 & 28.4 & 56.8 \\
\hline Moist & 360 & $\begin{array}{c}0-2.5 \\
>2.5\end{array}$ & $\begin{array}{l}1.07 \\
\text { ND }\end{array}$ & 26.75 & 47.53 & 28.4 & 33.3 \\
\hline
\end{tabular}

${ }^{a}$ Oftanol 1.5G, Mobay Chemical Corporation, Kansas City, Mo.

${ }^{b} \mathrm{ND}$, nondetectable $(\leq 0.045 \mathrm{ppm})$.

\section{Conclusions}

A more systematic and experimental approach to the study of soil insect ecology is required for better understanding and management of the scarab grub complex that infests turfgrass. The soil has been treated as a black box in which the consequences rather than the processes of insect behavior are measured. A lack of appropriate techniques for research on soil insect behavior has limited rapid advances in this area of ecological and entomological study.

We have documented a laboratory technique that allows for the precise study of scarab grub behavior in heterogeneous soil matrixes. It also can be used in the study of the interaction of scarab grubs, soil insecticides, and the soil environment in model systems. We believe this radiographic technique provides a unique view of a dynamic 


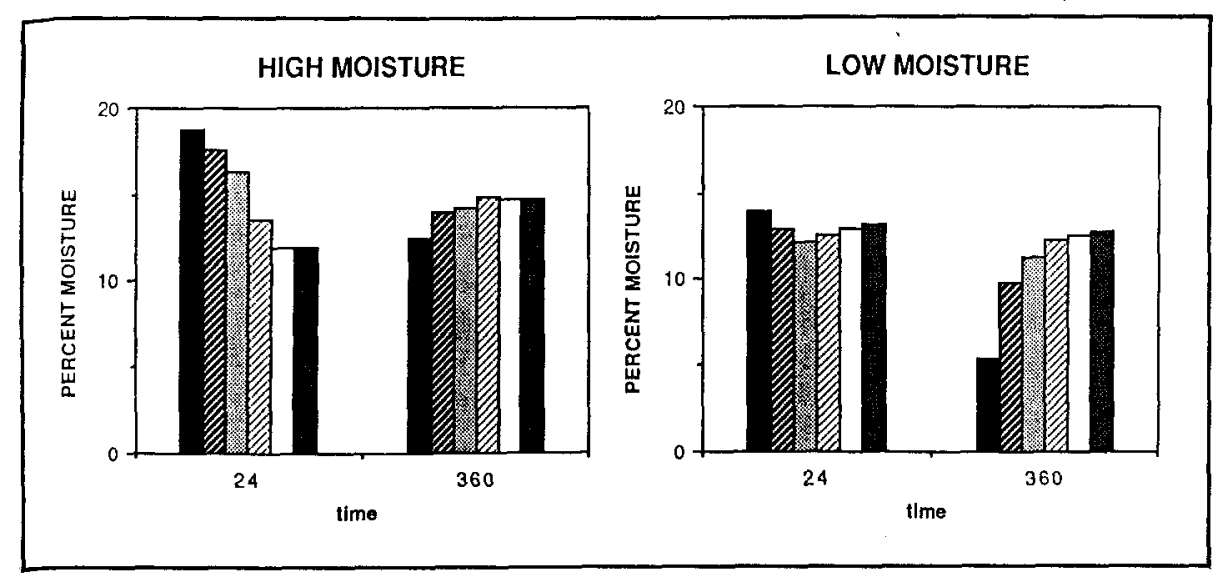

Fig. 11. Soil profile for bigh-and low-moisture treatments at beginning and end of the study of soil moisture and persistence and efficacy of isofenphos against grubs. Histogram bars (left to right) show percentage moisture at soil depth of $0-2.5,2.5-5.0,5.0-7.5,7.5-$ $15.0,15.0-22.5$, and $22.5-30.0 \mathrm{~cm}$.

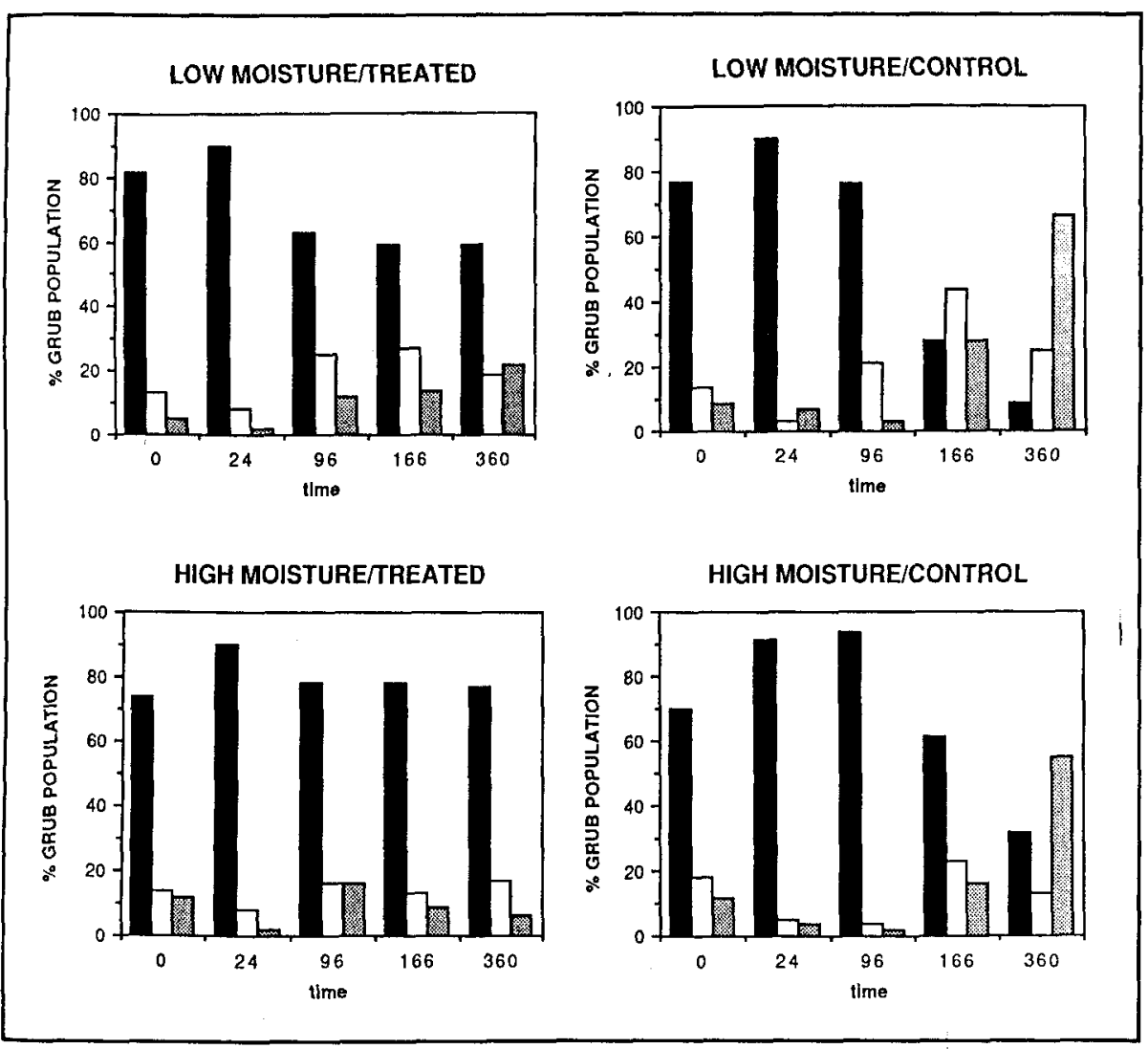

Fig. 12. Distribution of EC grub populations maintained at bigh and low moisture with and without addition of isofenphos to surface. Histogram bars (left to right) shou percentage EC population at soil deptbs of $\mathrm{O}-2.5,2.5-5.0$, and $>5 \mathrm{~cm}$.

soil system, and the results that we obtained appear to be consistent with past anecdotal reports of scarab grub behavior in the field. These studies have documented species-specific differences in the response of four scarab grub species to changes in soil moisture and temperature. They suggest it is important to examine the interaction of soil insect behavior, the soil physical environment, and insecticide movement and persistence as part of the development of effective management tactics for soil in-

We thank F. Consolie and L. Preston-Wilsey for their technical expertise in the development and execution of these studies, T. Spittler and G. Helf- man (Department of Food Science and Technology, New York State Agricultural Experiment Station, Geneva N.Y.) for use of analytic analysis facilities and development of analytic procedures, and J. Nyrop for suggestions on how best to present and analyze movement data. We acknowledge $\mathbf{F}$ Gould for suggesting that radiographs might be a useful tool for studying soil insect behavior. We are grateful for partial support for this research through grants from Mobay Chemical Corporation, Kansas City, Mo.; Rhone-Poulenc Corporation, Monmouth, N.J.; the New York State Turfgrass Association; and the Office for Research, Cornell University Agricultural Experiment Station, Ithaca, N.Y.

\section{References Cited}

Ahmad, S. \& Y.-S Ng. 1981. Further evidence of chlorpyrifos tolerance and partial resistance by the Japanese beetle (Coleoptera: Scarabaeidae). J. N. Y. Entomol. Soc. 89: 34-39.

Baker, P. B. 1986. Responses by Japanese and Oriental beetle grubs (Coleoptera: Scarabaeidae) to bendiocarb, chlorpyrifos, and isofenphos, J. Econ. Entomol. 79: 452-454.

Chapman, R. A. 1982. Persistence of insecticides in water and soil with special reference to $\mathrm{pH}$, pp. 65-69. In H. D. Niemczyk \& B. G. Joyner [eds.], Advances in turfgrass entomology. Chemlawn Corporation, Worthington, Ohio.

Criddle, N. 1918. The habits and control of white grubs in Manitoba. Agric. Gaz. Can. 5: 449454.

Doane, J. F., Y. W. Lee, J. Klinger \& N. D. Westcott. 1975. The orientation response of Ctenicera destructor and other wireworms to germinating corn and to carbon dioxide. Can. Entomol. 107: 1233-1252.

Dowdy, W. W. 1944. The influence of temperature on vertical migration of invertebrates inhabiting different soil types. Ecology 25: 449460.

Fisher, J. B., A. J. Keaster \& M. L. Fairchild. 1975. Seasonal vertical movement of wireworm larvae in Missouri: influence of soil temperature on the genus Melanotus and Conodertus. Ann. Ent. Soc. Am. 68: 1071-1073.

Forbes, S. A. 1907. On the life history, habits and economic relations of white grubs and May beetles, pp. 447-480. In Illinois Agricultural Experiment Station Bulletin.

Fulton, B. B. 1928. Some temperature relations of Melanotus (Coleoptera: Elateridae). J. Econ. Entomol. 21: 889-897.

Harris, C. R. 1972. Factors influencing the toxicity of insecticides in soil. Annu. Rev. Entomol. 17: $177-198$

1982. Factors influencing the toxicity of insecticides in soil, pp. 47-52. In H. D. Niemczyk \& B. G. Joyner [eds.], Advances in turfgrass entomology. Chemlawn Corporation, Worthington, Ohio.

Hawley, I. M. 1949. The effect of summer rainfall on Japanese beetle populations. J. N.Y. Entomol. Soc. 11: 136-144.

Kuhr, R. J. \& H. Tashiro. Distribution and persistence of chlorpyrifos and diazinon when applied to turf. Bull. Environ. Contam. Toxicol. 20: 652-656.
LaFrance, J. 1968. The seasonal movement of wireworms (Coleoptera: Elateridae) in relation 
to soil moisture and temperature in the organic soils of southwestern Quebec. Can. Entomol. 100: 801-807.

Mail, G. A. 1930. Winter soil temperature and their relationship to subterranean insect survival. J. Agric. Res. 41: 571-592.

McCollock, J. W. \& W. P. Hayes. 1923. Soil temperatures and its influence on white grub activity. Ecology 4: 29-36.

McGill, R., J. W. Tukey \& W. A. Larsen. 1978. Variations of boxplots. Am. Stat. 32: 12-16.

$\mathrm{Ng}$, Y.-S. \& S. Ahmad. 1979. Resistance to dieldrin and tolerance to chlorpyrifos and bendiocarb in a northern New Jersey population of the Japanese beetle. J. Econ. Entomol. 72: 698-700.

Niemczyk, H. D. 1987. The influence of application timing and postreatment irrigation on the fate and effectiveness of isofenphos for control of Japanese beetle (Coleoptera: Scarabaeidae) larvae in turfgrass. J. Econ. Entomol. 80: 465470.

Niemczyk, H. D. \& R. A. Chapman. 1987. Evidence of enhanced degradation of isofenphos in turfgrass thatch and soil. J. Econ. Entomol.
80: 880-882.

Niemczyk, H. D. \& H. R. Krueger. 1982. Binding of insecticides on turfgrass thatch, pp. 61-63. In H. D. Niemczyk \& B. G. Joyner [eds.], Advances in turfgrass entomology. Chemlawn Corporation, Worthington, Ohio.

Niemczyk, H. D., H. R. Krueger \& K. O. Lawrence. 1977. Thatch influences movement of soil insecticides. Ohio Rep. 62: 26-28.

Racke, K. D. \& J. R. Coats. 1987. Enhanced degradation isofenphos by soil microorganisms. J. Agric. Food Chem. 35: 94-99.

Sears, M. K. \& R. A. Chapman. 1982. Persistence and movement of four insecticides applied to turfgrass, pp. 57-59. In H. D. Niemczyk \& B. G. Joyner [eds.], Advances in turfgrass entomology. Chemlawn Corporation, Worthington, Ohio.

Smith, W. G. \& G. M. Wilson. [eds.]. 1987. 1988 New York state pesticide recommendations. Chemicals-Pesticides Program, College of Agricultural and Life Sciences, Cornell University, Ithaca N.Y.

Tashiro, H. 1982. Distribution and persistence of chlorpyrifos and diazinon when applied to turf, pp. 53-56. In H. D. Niemczyk \& B. G. Joyner [eds.], Advances in turfgrass entomology. Chemlawn Corporation, Worthington, Ohio. 1987. Turfgrass insects of the United States and Canada. Cornell University Press, Ithaca, N.Y.

Tashiro, H. \& R. J. Kuhr. 1978. Some factors influencing the toxicity of soil applications of chlorpyrifos and diazinon to European chafer grubs. J. Econ. Entomol. 71: 904-907.

Villani, M. G. \& F. Gould. 1986 . Use of radiographs for movement analysis of the corn wireworm, Melanotus communis (Coleoptera: Elateridae). Environ. Entomol. 15: 462-464.

Vittum, P. J. 1985. Effect of timing of application on effectiveness of isofenphos, isazophos, and diazinon on Japanese beetle (Coleoptera: Scarabaeidae) grubs in turf. J. Econ. Entomol. 78: 172-184.

1986. Keeping lawns free of white grubs. Lawn Care Ind. 10(4): 28-32.

Received for publication 12 January 1988; ac cepted 22 June 1988. 